\title{
Impact of Capital Gains Tax on Stock Investment in Pakistan
}

\author{
*Khalid Mahmood Lodhi' ${ }^{1}$ S. M. Amir Shah² \\ ${ }^{1}$ Iqra University Islamabad, Pakistan \\ ${ }^{2}$ A.I.O.U, Islamabad, Pakistan \\ *kmlodhi@yahoo.com
}

\begin{abstract}
This study analyzes the impact of capital gains tax on stocks investment in Pakistan. Whenever there is an increase in the value of a capital asset realized over its cost it is termed as capital gain and the tax imposed thereof is called Capital Gains Tax. The study finds that levy of Capital Gains Tax results in lower volume of stock investment and lesser growth in assets/securities whereas the revenues have also declined as further investments have declined due to the fears of documentation of small investors by the tax authorities.
\end{abstract}

Keywords: Economic activity in Stock market, Tax Policy, Reforms, Stock market revenue, Securities

\section{Introduction}

The Impact of Capital Gains Tax on Stock market in Pakistan is debatable. However, a critical analysis of the International market reveals that levying higher rates of Capital Gains Tax results in lower volume of stock investment and lesser growth in assets/securities whereas the revenues have also declined ${ }^{\dagger}$. A large number of economic income in Pakistan has not been taxed which is in the form of Capital gains. Finance Bill 2010 ended Capital Gains Tax exemption on securities and every gain arising out of sale of a security is liable to a tax as per predefined tax schedule. Often referred to as Taxing the Wealthy, one of the Pros of Capital Gains Tax argues that lack of imposing Capital Gains Tax favors investments in assets that are expected to appreciate over assets that earn taxable income (The Taxation of Capital Gains, September 2009). For example, levying a tax on land would not affect the supply of land. However, this can lower its price relative to other investments thereby adding productivity and growth in the economy. To avoid distorted investment decisions and equity implications, levying Capital Gains Tax is inevitable. Privy to what good CGT can bring in the economy, there are some Cons of imposing CGT as well. For instance, the seller of a security or an asset may defer the sale to avoid the tax.

The major economic problem of Pakistan is the lower tax revenues against the expenditures (Country Procurement Assessment Report; World Bank, 2001) which have resulted into huge budget deficits for last many years. The tax revenue has not been sufficient to cater the country's financial needs, which led government to borrow from domestic and international creditors. The key issues of the taxation system and revenue organization during pre-reform period in Pakistan were; discretionary powers with tax officials, corruption, narrow tax base, high tax rates, SRO culture, low share of direct taxes, low buoyancy, heavy reliance on withholding taxes, delayed refund payments and a non-friendly environment in tax offices (Country Procurement Assessment Report; World Bank 2001). These factors not only reduced the tax collection but also resulted in the loss of credibility of the tax machinery in public. Within income tax, the rates for the corporate sector were exceptionally high which not only discouraged tax compliance but also encouraged tax avoidance and evasion. In this backdrop, there was a need to address these issues in a manner that the taxation system becomes less complicated and cumbersome. In year 2000, the government constituted a Task Force on Reform of Tax Administration, which presented its report in April 2001. The focus of the reform report was to raise tax revenues through simplified tax laws and procedures and a congenial business environment and to regain the taxpayers' confidence in revenue organization. CGT was

\footnotetext{
* Khalid Mahmood Lodhi is a PhD Scholar at Iqra University Islamabad.

${ }^{\dagger}$ The Effect of Capital Gains Tax Rises on Revenues, Adam Smith Institute, May 2010; estimated revenue losses from capital gains Tax increases.
} 
proposed on the basis of this report with a notion that taxing capital gains would increase the progressivity of the tax system. Moreover, it was concluded that not taxing this income is regressive.

As per Income Tax Ordinance 2001, the corporate income tax rates were $66 \%$ and as a policy change were gradually reduced to $35 \%$. Economists agree that the higher rates usually discourage the businesses, large corporations and other taxpayers and resultantly there is more tax evasion, corruption, insufficient revenue generation and eventually under development and poverty. The income tax rates were on the higher side before the taxation reforms in the country. The cost of doing business was very high, bankers were reluctant to invest and particularly foreign investors found the higher rates an impediment. Keeping in view these factors overall individual and corporate income tax rates were reduced. This study focused on the impact of CGT on the performance of Stock Market in Pakistan. The study is unique in a way as no prior research has been conducted in Pakistan on the Impact of CGT on stock market. The concept of CGT is relatively new in Pakistan as the Impact of CGT on stock market is still uncertain. This study tried to explore and analyze the impact of CGT on stock market. The study discussed critically the statement "Would the reduction in CGT rates on Capital gains will generate higher revenues from Stock Market." In some cases, we may find the taxation reforms have not been able to produce the desired outcome; therefore, we may need some other measures and changes along with reforms to ensure increased tax revenues, growth and economic activity. We need to know that; Did Levy of CGT on stock has negative or positive effect on the Stock market turnover/asset growth. To answer this question the study mainly depends on the secondary data like Economic Survey 2009-10, 2010-11, FBR Data Bank, SBP data, and related research articles. The research focused on the answer to the above question based on the Research model.

The objective of the study: The objective of study is to know the impact of CGT on Stock Market to know the impact of decrease as well as increase in CGT rates on profitability in Stock Market. For last many years, lower tax revenue results in to unsustainable fiscal imbalance. The government, as a result depend on heavy borrowing from the banking system, which in turn exerts pressure on short-term interest rates, with adverse implications for inflationary expectations, private sector credit and overall macroeconomic stability. The only possibility of the resource generation is none other than sound tax system generating more revenues without creating distortions in the economy. Pakistan is entangled with the inappropriate taxation policy ${ }^{\ddagger}$ and structure leading to lower tax-GDP ratio in the region, narrow tax base and thus insufficient resources available for poverty alleviation. The current tax-GDP ratio is hardly 9\%; out of 170 million population only 3.2 million are the National Tax Number (NTN) holders and less than 1\% pay income tax. The ratio of direct and indirect taxes has also been an issue, nevertheless, with the passage of time the share of direct taxes kept rising and reached around $40 \%$. Another serious problem is financial corruption, which keeps under immense pressures the fiscal managers. The World Bank Study 2009 about the FBR Reforms reveals that there is a tax gap of around Rs.800 billion due to malpractices in the organization. There are various sources of federal revenues; however, four taxes are the major sources of federal government tax revenues. The federal government collects more than $90 \%$ tax revenues. Four major taxes are the Direct Taxes/Income tax on corporations, firms, individuals and associations of persons and Indirect Taxes including GST, Federal Excises and Customs duties.

\section{Graph 1: The share of each tax}

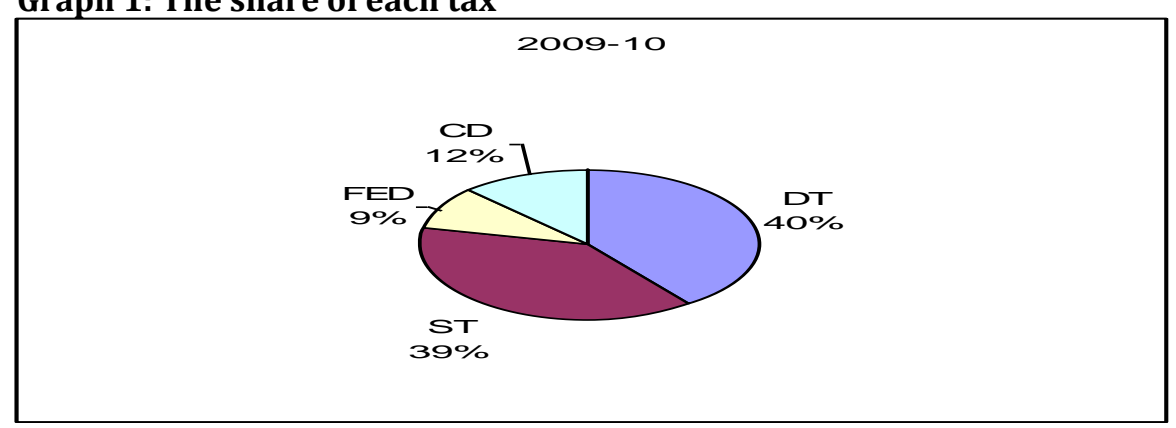

Source: FBR data base

\footnotetext{
\#(Business Recorder (Date: 2011-05-23 printing date: 04-11-2011; 07:07:04)
} 
Various foreign markets have a Capital Gains Tax imposed on gains from investments in equities and mutual funds. India, for instance, is subject to a CGT of $10 \%$ for investments made for less than one year. Investments held for more than a year are exempt from taxes. The US and China follow tax schedules based on income levels and residence status. Malaysia and Singapore, on the other hand, do not have a CGT on investment in securities. Major objective of a revenue organization like FBR is revenue generation by creating taxpayers friendly environment and by avoiding the economic distortions in the country. Nonetheless, the ultimate objective of the taxation reforms program is the economic growth, development, and welfare of the people. Economic growth depends on the performance of various sectors in the economy. Higher rates usually discourage the businesses, large corporations and other taxpayers and resultantly there is more tax evasion, corruption, insufficient revenue generation and eventually under development and poverty. The cost of doing business was very high, bankers were reluctant to invest and particularly foreign investors found the higher rates an impediment. In the first four years of the twenty-first century, Pakistan's KSE 100 Index was the best-performing stock market index in the world as declared by the international magazine "Business Week, October 2002". The stock market capitalization of listed companies in Pakistan was valued at \$5,937 million in 2005 by the World Bank (Data Finance, 2007).

\section{Literature Review}

The literature contended that the prevailing taxation faced the problems like corruption, narrow tax base, high tax rates, smuggling, statutory regulatory Orders (SROs) culture, heavy reliance on withholding taxes, delayed refund payments, low salaries of tax officials and unfriendly behavior of tax collectors (Report of Task Force, 2001, World Bank, 2001). These factors not only reduced the tax collection but also resulted in the loss of the credibility of tax machinery in the public. With such type of serious issues it is hard to attract FDI, promote business, healthy competition and grow the economy. In the past various steps were taken by the then governments to improve the taxation system. These efforts seemed lacking strong political will and were on the small scale. Some of the significant steps taken in the past are a substantial decline in the customs rates i.e. $92 \%$ to $25 \%$, resultantly the revenue from CD increased by 50\% during 1994 to 2009-10 (FBR Year Book, 2010-11). The size of undocumented economy had exceeded the size of the documented economy and according to World Bank estimates (Fiza, 2003), there was a potential of raising another 600 billion rupees as revenue by bringing the informal sector of the economy into the tax system. Therefore, the government by realizing this need launched a survey for the documentation of economy in year 2000-01 mainly to enhance the tax base, revenue and to document the economy. According to Adam Smith Institute (May 2010) evidence suggests clearly that increases in CGT above a very modest level result in decreases in revenue and decrease in CGT result in increase in revenue. Poterba (1989) argued that decreases in capital gains tax increase the attractiveness of becoming an entrepreneur to salaried employees. Saxton (1997) revealed in a US Congress joint committee study that reduction of CGT would have a positive impact on economic and employment growth. In addition, a capital gains tax reduction would partly abate the problem of taxing inflationary gains. An interesting Study conducted by IRET finds that higher tax rates on capital income would discourage investment and result in smaller capital stock each time when the CGT percentage is higher.

There is voluminous literature on the taxes and fiscal issues in the world revealing various policy options for a suitable taxation structure. Recently there has been a broad consensus amongst tax policy makers that taxes ought to be used as instruments of social and economic policy. Steeply progressive taxes were thought of as a social good because they contribute to economic redistribution in society. In case of Pakistan high income tax rates lead to tax evasion and other indirect taxes like sales tax and excise duties lead to price hike hence more burden on poor. Fiza (2003), Jonas and Linda (2007) simulated the effects of taxes on products and /or nutrients aimed at encouraging healthier grain consumption. Hinnosaar (2004) estimated the impact of changes in social benefits and taxes on Estonian labor market that was analyzed using a simple computable general equilibrium model. He used the model from Bovenberg et al. (2000), with the addition of an efficiency wage part based on (Shapiro \& Stiglitz, 1984). Shapiro \& Stiglitz, (1984) explored the Ralph Review's assumption that the unfavorable effect of tax reforms on small business has been adequately counterbalanced by reduced taxation compliance costs. Refaqat (2002) assessed the welfare impact of GST reform on Pakistani households between 1990 and 2001. Romer and Romer (2007) of the view that legislated tax increases designed to reduce a persistent budget deficit appear to have much smaller output costs than other tax increases. Similarly, increased taxes can have a negative effect on the investments leading to low profits 
forcing investors to pull their investments leading to distortions in the market and poor GDP growth. Dunstan et al. (2007) considered tax changes could have very different effects: tax cuts designed to spur savings could be mildly contractionary, while company tax cuts will tend to be expansionary.

A recent analysis of the stock market 2010-11 reveals that Capital Gains Tax (CGT) has scared away retail investors. The turnover of the shares has declined drastically in 2010-11 as compared to steady progression in 2007-08. Collapse in volume means collapse in income, hence the fixation of blame in tax regime. The investors can be encouraged to increase the liquidity of the market by lowering the CGT, which will ultimately produce more risk takers in the market. i.e., individual brokers willing to take the risk of purchasing shares for expected return. A recent analysis of the stock market 2010-11 reveals that collapse in share traded volumes by 8 times relative to 3-4 years ago shows that Capital Gains Tax (CGT) has scared away retail investors. The turnover over of shares has declined drastically in 2010-11 as compared to steady progression in 2007-8. Collapse in volume means collapse in income, hence the fixation of blame on tax regime. The investors can be encouraged to increase liquidity of the market by lowering the CGT, which will ultimately produce more risk takers in the market i.e. individual brokers willing to take the risk of purchasing shares for expected return.

\section{Graph 2: Listed Securities on Islamabad Stock Exchange (ISE)}

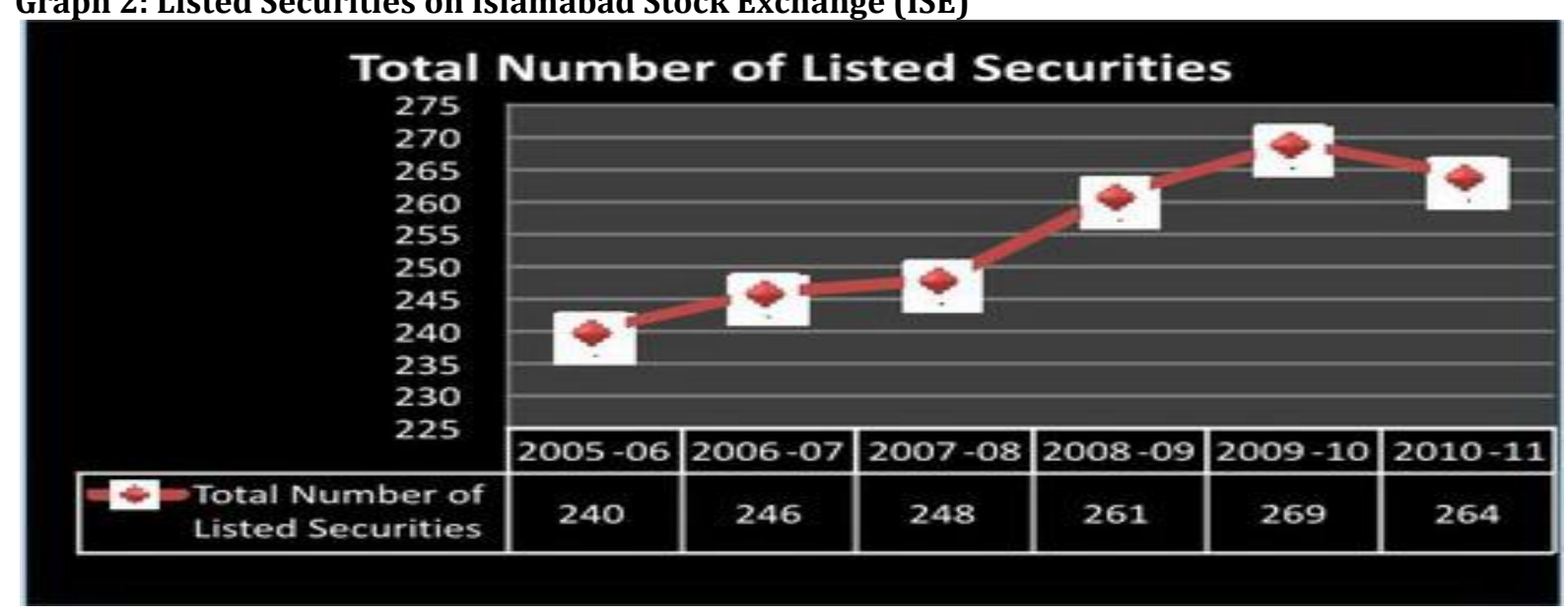

\section{Graph 3: Turnover of Shares on ISE}

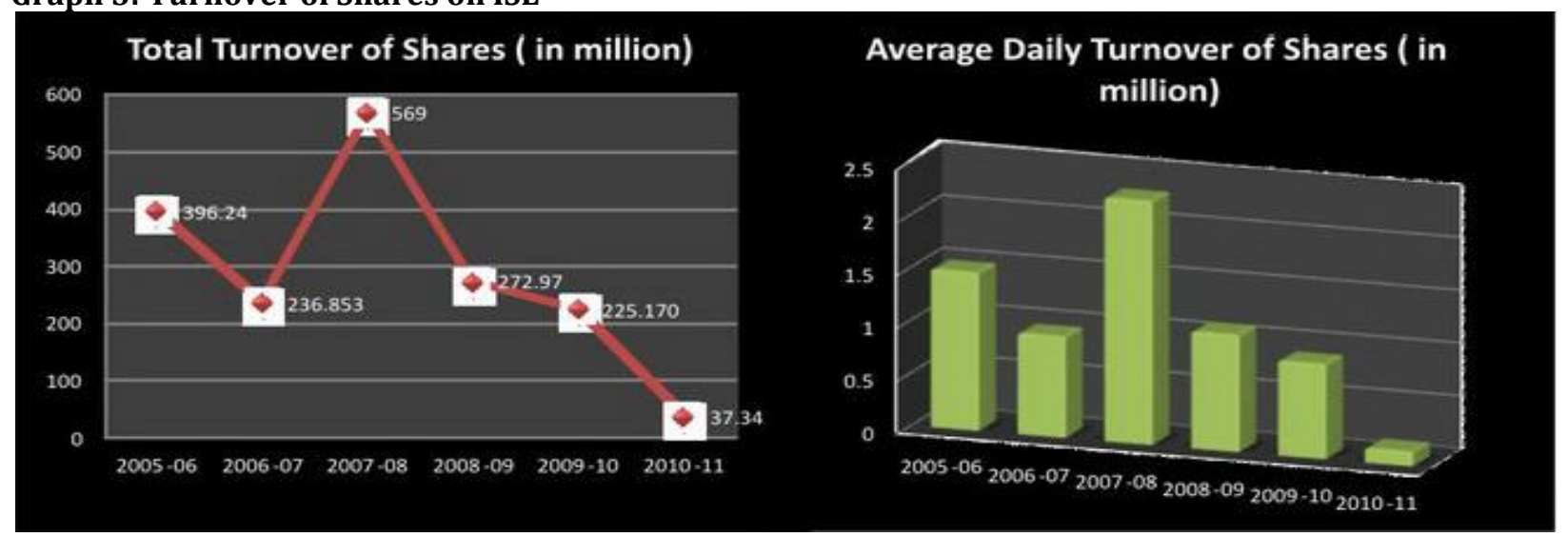

Source ISE Annual Report 2010-11

The Finance Bill 2010 clearly outlines CGT on equity investment held for less than one year. Due to the tax on equities, we understand that investment in an equity fund will also be liable to pay the CGT. However, the imposition of CGT on other categories, including Income and Money Market Funds is uncertain, as the underlying assets (apart from TFCs) are not subject to CGT. Under the Finance Bill 2010, investments held for less than 6 months will be liable for a CGT of 10\%, investment between 6 to 12 months will be subject to $7.5 \%$ 
CGT and investment over 12 months will be tax-exempt. As outlined in Graph-5 below, the CGT will become more aggressive with the period.

Research Model: This research is based on both qualitative and quantitative research methods to yield more appropriate and effective outcome. Figure 1.1 illustrates the relationship between independent variables and dependent variables. Independent variables include tax policy reforms and administrative reforms including tax structure systems, tariffs, systems \& procedures whereas the dependent variables include impact of levy of CGT on trade in Stock market shares investment. Following is the model of independent and dependent variables. The research will travel through the shaded path in both the models. Hypotheses Statements: To understand the relationship between increase and decrease of Capital Gains tax on the Stocks investment in Pakistan. Following hypothesis have been developed for further research:

H0: Levy of CGT on stocks has negative effect on the Stock market turnover/asset growth

H1: Levy of CGT on stocks has positive effect on the Stock market turnover/asset growth.

\section{Figure-1: Theoretical Framework}

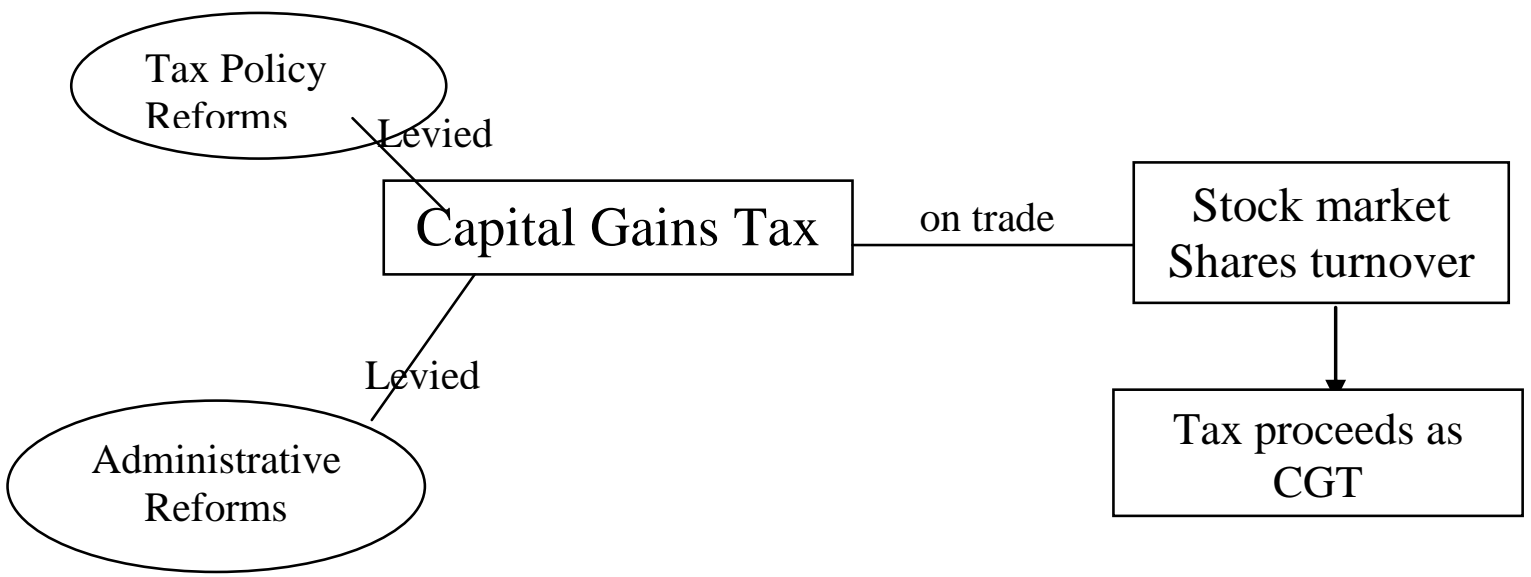

\section{Methodology}

This research study is based on secondary data. The impact of CGT tax policy reforms on Stock market growth sector has been selected for this study to understand the impact of levy of CGT on trade in Stock market shares investment. The analysis period was from the CY2005 to CY 2006 and CY2009 to CY2010. The data was taken from statistics department of the State Bank of Pakistan, FBR Year book 2000-01, 2001-02, 200203, 2005-06, Economic Surveys of Pakistan from 2000-01 to 2010-11, 2003-04, Annual Plan 2011-12, Pakistan Income Tax Ordinance 2001, the annual reports of Islamabad Stock Exchange (ISE) and Karachi Stock Exchange (KSE) operating in Pakistan. The analysis has been done and shown through bar charts, graphic presentation and tabulated information.

\section{Analysis and Discussion}

The capital Gains Tax (CGT) imposed in FY 2010 was highly criticized by some of the stakeholders for many reasons. From the investor's point of view, it would hamper and discourage the investment in stocks. This implies that gains in one period could be offset with loses in another with the net effect resulting in a lower tax. Nonetheless, capital gains are treated as a separate block of income and are not adjustable against other forms of tax. In the event that mutual funds fall under CGT, the incidence of the tax plays an important role. The tax can be levied either directly on the mutual fund assets when securities are traded; or on the investor when units of the fund are redeemed. Moreover, it is beneficial for the investor to bear the incidence of the tax. Firstly, an investor can control the holding period of his investment. Moreover, by holding the investment for over 12 months, the investor can avoid any tax deductions while capitalizing on short-term trading opportunities. In case CGT is levied at investor level (rather than direct levy on mutual funds), Asset Management Companies (AMCs) will not act as tax collection agents. Instead, the CGT will be collected when 
an individual files for taxes. An 'Advance Tax' clause highlights that taxpayers filing for quarterly taxes would be liable to a 2\% CGT for securities held less than 6 months and a 1.5\% CGT for a holding period of 6-12 months. The remaining burden of the CGT will be paid at the end of the fiscal year. Similarly, economists believe that people would divert their investments towards other areas to avoid the taxation and documentation. A major reason for reduction in stock investment after levy of CGT is that some investors, particularly small investors, prefer to avoid documentation and remain out of tax net and make investments in less documented and taxed sectors of economy. That has resulted in lower tax revenues keeping a big tax gap. The last two years tax receipts confirm these claims and the expectations never proved true and tax collection from the stocks remained far below than potential. Following table shows the details;

\begin{tabular}{llll} 
Table 1: Tax Collection from Stocks & & Million & Million \\
\hline Heads & Rates & $\mathbf{2 0 0 9 - 1 0}$ & $\mathbf{2 0 1 0 - 1 1}$ \\
\hline On purchase/sale of shares & $0.01 \%$ & 644.8 & 439.4 \\
Commission on trading of shares & $0.01 \%$ & 0 & 15.3 \\
On trading of shares & $0.01 \%$ & 14 & 45.5 \\
On financing of carryover share trades & $10.0 \%$ & 0.4 & 0.8 \\
Total & & 659.2 & 501.0 \\
\hline
\end{tabular}

Four items namely; purchase and sale of shares, commission on trading shares, on trading shares and on financing of carryover shares trades were included in the tax net. In the year 2009-10 the collection was more than Rs. half billion, however, next year in 2010-11 it fell sharply. The major item with significant share was tax on purchase and sale of shares, which shared about $98 \%$ of the total collection. It followed by collection from commission on trading of shares with $2 \%$ share in total collection from stocks. In the next year the trend was almost same however, overall collection declined by $24 \%$, which is evident from Graph-4. The collection from major contributor i.e. purchases and sale of shares declined sharply and that affected the overall revenue from stocks.

\section{Graph 4: Growth in Collection from Stock Exchange}

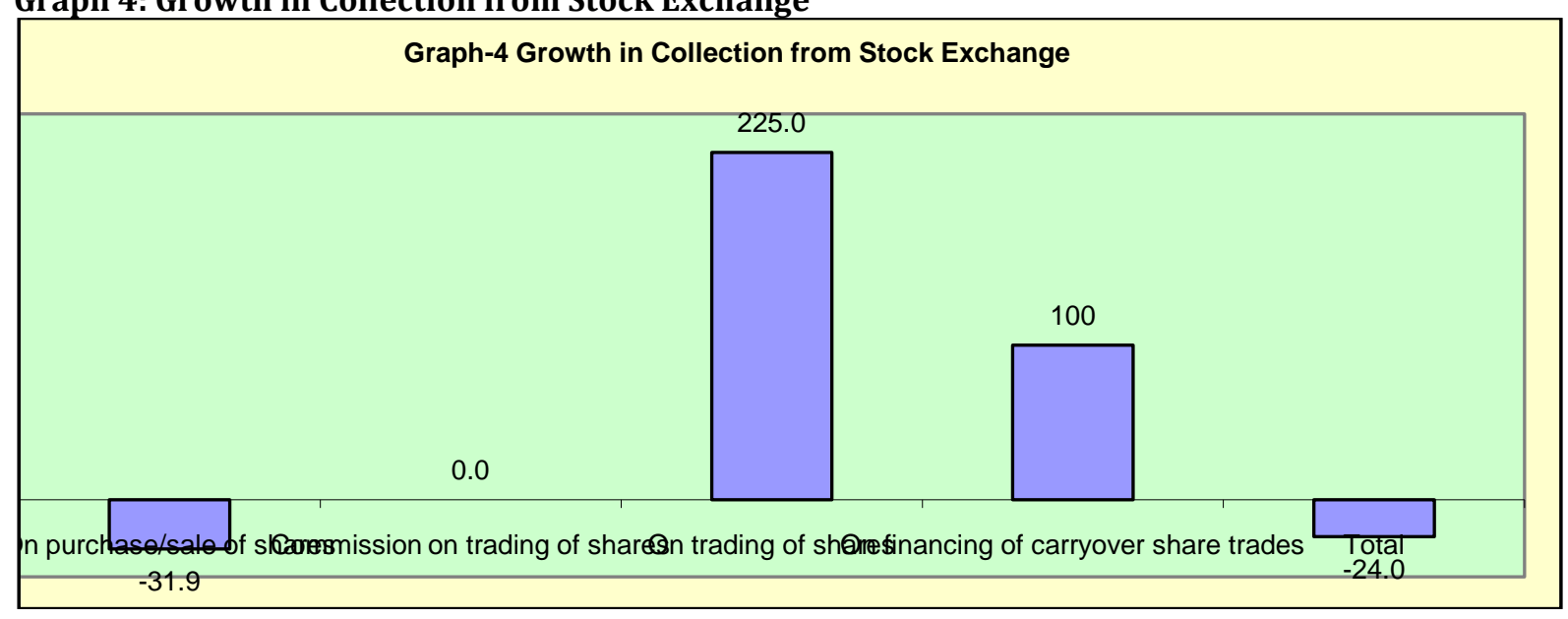

Table 2: Capital Gains Tax (CGT) Vs Turnover of Shares

\begin{tabular}{lll}
\hline Years & CGT Rate & Total Turnover \\
\hline $2005-6$ & Nil & 396.24 \\
$2006-7$ & Nil & 236.853 \\
$2007-8$ & Nil & 569 \\
$2008-9$ & 0.01 & 272.97 \\
$2009-10$ & 0.01 & 225.17 \\
$2010-11$ & 0.01 & 37.343 \\
\hline
\end{tabular}

The trading volume remained low during 2008-9, 2009-10 and 2010-11 due to the imposition CGT. Average daily turnover of shares drastically decreased. This shows the behavioral trend of the investor to secure his 
investment. However, the behavioral trend of the general investor can be changed by minimizing the rate of CGT to increase market liquidity and encourage investments. Moreover, the trust of investors can also be gained by training and development considering the market elasticity.

Table 3: Market performance

\begin{tabular}{|c|c|c|c|c|c|c|}
\hline DESCRIPTION & 2005-06 & 2006-07 & 2007-08 & 2008-09 & 2009-10 & $\begin{array}{l}\text { In million } \\
2010-11 \\
\end{array}$ \\
\hline Total Number of listed securities & 240 & 246 & 248 & 261 & 271 & 264 \\
\hline $\begin{array}{l}\text { Total listed paid up capital (Rs. In } \\
\text { Billion) }\end{array}$ & 375 & 489 & 551 & 608.4 & 715.650 & 726.960 \\
\hline $\begin{array}{l}\text { Total market capitalization (Rs. In } \\
\text { Billion) }\end{array}$ & 2101.59 & 3060.61 & 2872.0 & 1705.02 & 2261.69 & 2621.07 \\
\hline ISE 10 Index & 2633.9 & 2716 & 2749.64 & 1713.03 & 2441.15 & 2722.83 \\
\hline New securities listed during the year & 6 & 12 & 7 & 15 & 13 & 5 \\
\hline $\begin{array}{l}\text { Listed paid up capital New } \\
\text { companies (Rs. In millions) }\end{array}$ & 5020 & 51733 & 18599 & 11881.7 & 26174.715 & - \\
\hline $\begin{array}{l}\text { Total turnover of shares (Rs. In } \\
\text { millions) }\end{array}$ & 396.24 & 236.853 & 569 & 272.97 & 225.170 & 37.373 \\
\hline $\begin{array}{l}\text { Average daily turnover of shares (Rs. } \\
\text { In millions) }\end{array}$ & 1.5 & 0.96 & 2.31 & 1.11 & 0.9 & 0.14 \\
\hline
\end{tabular}

Graph-5: Slabs of CGT for securities under finance bill 2010

Graph-5 Slabs of CGT for securities under finance bill 2010

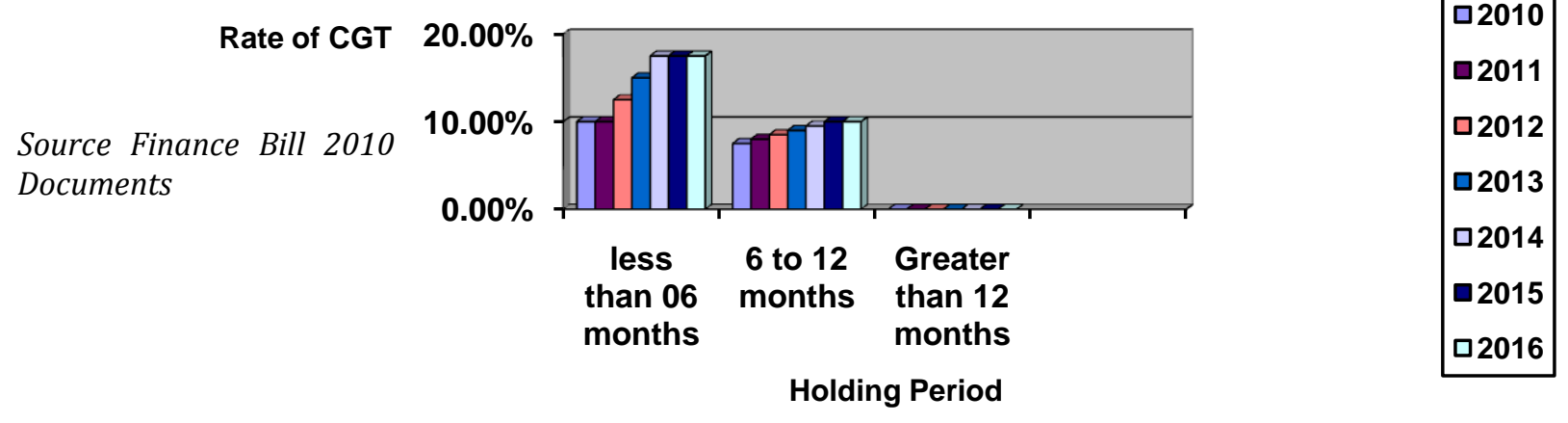

The securities remained volatile in 2010-11. The trading volume remained very low during the year. The trading volumes decreased mainly due to the imposition of Capital Gains Tax, consistent rise in capital gains tax, consistent rise in discount rates and lack of leverage products. Average daily turnover drastically decreased from 0.90 million in 2010 to 0.14 million in 2011. The market capitalization also grew 13.2 percent that stood at Rs. 2621.07 billion as of June 30, 2011. The participation of the investors in the securities market remained unsatisfactory. Nevertheless, the overall economic slowdown and slump in the economy is also one of the factors responsible for lower investments in the stocks.

Discussion: The results of the present study are in line the previous studies like Adam Smith Institute (May 2010) evidence suggests clearly that increases in CGT above a very modest level result in decreases in revenue and decrease in CGT result in increase in revenue. Poterba (1989) argued that decreases in capital gains tax increase the attractiveness of becoming an entrepreneur to salaried employees. Saxton (1997) revealed in a US Congress joint committee study that reduction of CGT would have a positive impact on economic and employment growth. In addition, a capital gains tax reduction would partly abate the problem of taxing inflationary gains. An interesting Study conducted by IRET finds that higher tax rates on capital income would discourage investment and result in smaller capital stock each time when the CGT percentage is higher. Fiza (2003), Jonas and Linda (2007) simulated the effects of taxes on products and /or nutrients 
aimed at encouraging healthier grain consumption. Hinnosaar (2004) estimated the impact of changes in social benefits and taxes on Estonian labor market that was analyzed using a simple computable general equilibrium model. He used the model from Bovenberg et al. (2000), with the addition of an efficiency wage part based on (Shapiro \& Stiglitz, 1984). Binh and John (2002) explored the Ralph Review's assumption that the unfavorable effect of tax reforms on small business has been adequately counterbalanced by reduced taxation compliance costs.

\section{Conclusion and Recommendations}

The study has found that the preliminary impact of the introduction of CGT has been negative. Initially four items i.e. purchase and sale of shares, commission on trading shares, on trading shares and on financing of carryover shares trades were included in the tax net. The data confirms that in the first year of tax imposition the collection, albeit slow and lower than expectations; however, revenue started pouring in. The first year witnessed a collection of more than Rs. half billion, however, next year it could not keep the pace and fell short of expectations. The major reason for the decline in stocks investment may be attributed to the imposition of the CGT; nevertheless, severe economic recession is also the possible factor behind this slowdown in the stocks business. The analysis revealed that the major item with significant share was tax on purchase and sale of shares, which shared about $98 \%$ of the total collection. It was followed by collection from trading of shares with $2 \%$ share in total collection from stocks. In the next year the trend was almost same, however, overall collection declined by $24 \%$. After the analysis of CGT and its implications on the stock investments in Pakistan, it is obvious that the confidence of investors needs to be restored first because they are holding their investments to avoid CGT. Lowering CGT cannot only encourage investors to sell shares but would also revitalize the overall market mechanism.

These low growth rates can be partly attributed to counterproductive tax policies that undermine long-term growth by discouraging saving and investment. Although broad tax reform is needed to address the deficiencies in the tax code, many economists believe that reducing the capital gains tax rate is an important step in the right direction. The effects of a capital gains tax reduction should not be overstated; nonetheless, its beneficial effects on the economy would make a significant contribution to long-term growth. It is also proposed that the CGT rates may further be reduced. It will definitely reduce the evasion and shall enhance the revenue. Tax Amnesty schemes have been experimented in Pakistan in other sectors of economy to encourage investors/taxpayers to declare their past investments without being penalized. A Tax Amnesty scheme may be announced specifically for stock investments by the government, for particular period like one or two years specifying that if declared in amnesty, tax authorities would not ask for sources of investments of previous stock investments, after paying some lump sum amount of tax on all previous investments. This could be helpful, the investor's fear of tax net could also be addressed, and they can be encouraged to declare previous investments and make more investments in future more liberally and without hesitation or fear. This step is also likely to boost stock investments after investors' confidence is restored and it would raise simultaneously the tax collection and ensure documentation of economy.

Future Research: This study explores the effects of levy of CGT on stock investments in Pakistan. CGT is a new tax and data reference range is very narrow, hence it is difficult to analyze its accurate empirical results to determine the identified trends in stock market. However, the study has provided a base for further research in the area to make an empirical analysis. The future researchers and students would find this study helpful for detailed empirical analysis after getting further data for analysis.

\section{References}

Bovenberg, A. L., Johan, J. G. \& Ruud, A. M. (2000). Tax Reform and the Dutch Labor Market. Journal of Public Economics, 78, 193-214.

CBR Quarterly Review April-June. (2002). Central Board of Revenue, Pakistan CBR Yearbooks. (2000-01 to 2008-09). Central Board of Revenue, Pakistan Cigarette Taxes Burn Smokers' Cash; New Paltz University.

Dunstan, A., Hargreaves, D. \& Karagedikli, 0. (2007). The effect of Fiscal policy on Business cycle, Reserve Bank of New Zealand. Bulletin, 70(1). 
Economic Surveys of Pakistan. (2003-04 to 2010-11). Finance Division, Government of Pakistan. Federal Board of Revenue, Pakistan. (2010). Pakistan Income Tax Ordinance, (2001).

Fiza, K. (2003). Promotion of documentation of economy problems, prospects and solutions, 84th Advanced Course in Public Sector Management, National Institute Of Public Administration, Lahore and http://www.dawn.com/2005/05/14/ebr1.htm.

Government of Pakistan, Report of Task Force on Reform of Tax Administration. (2001).

Hinnosaar, M. (2004). Estonian Labor Market Institutions within a General Equilibrium Framework, Working Papers of Eesti Pank, 5.

Poterba, J. M. (1989). Venture Capital and Capital Gains Taxation, in Tax Policy and the Economy, ed. Lawrence H. Summers, 1989.

Saxton, J. (1997). The economic effect of capital gains taxation, A joint economic committee stud, US Congress

Jonas, N. \& Lind, T. (2007). The Impact of Tax Reforms Designed to Encourage a Healthier Grain Consumption, Umeå University, Department of Economics in its series Umeå Economic Studies with number 717.

Refaqat, S. (2002). Redistributive Impact of GST Tax Reform: Pakistan, 1990-2001. The Pakistan Development Review, 44(4), 841-862.

Romer, C. D. \& Romer, D. H. (2007). The Macroeconomic effects of Tax Changes: Estimates based on a new measure of fiscal shocks; University of California, Berkeley.

Shapiro, C. \& Stiglitz, J. E. (1984). Equilibrium Unemployment as a Worker Discipline Device. American Economic Review, 74(3), 433-444.

World Bank/Government of Pakistan. Progress and Prospects Report. (2001). from (www.worldbank.org/sar/sa.nsf/0/c3e79a8d2720625385256a090074d943?OpenDocument). 